\title{
Migration Control and Detention of Migrants and Asylum Seekers - Motivations, Rationale and Challenges
}

\author{
Š́rka Dušková*
}

DOI: $10.21827 / 59 \mathrm{db} 69 \mathrm{a} 9004 \mathrm{df}$

Detention of migrants in Europe has become an increasingly common measure to deal with the growing number of people crossing EU borders seeking asylum. Detention is presented as a rational response to the need for 'border control' despite the growing international and European jurisprudence and campaigns calling for a more careful and restrained approach to its use. Especially in some of the EU member states, the disparity between international legal standards and the almost automatic use of detention of an irregular migrant or asylum seeker is a cause for attention. The article first offers an overview of the relevant legal standards for detention of migrants and complements this with relevant data about its practical use. Drawing on previous work in this area, the author suggests that there are various complementary motivations for the use of detention of migrants. As only the practical motive can be the one to justify detention formally and legally, the article offers an analysis of rationality of the use of detention visà-vis the known alternatives. The predominance of different kinds of alternatives in the EU to detention is also explored. The article concludes with the suggestion that to fulfil all state motivations for the use of detention, the introduction of a range of alternatives complemented with the change of discourse may in fact be a rational move for states.

\section{Introduction}

Immigration has increasingly been at the center of the political discussion in the European Union (EU) in recent years, supported by the ever-growing number of individuals crossing EU borders seeking asylum. ${ }^{1}$ The political rhetoric securitizing migration emphasizes the need for effective migration control. In practice, this leads to the normalization of the use of detention of migrants as the primary means to achieve this goal. ${ }^{2}$ At the same time, a growing number of international jurisprudence may be detected, which emphasizes that deprivation of liberty is always a serious interference

Ph.D. candidate at Faculty of Law, department of Constitutional Law and Political Science, Masaryk University, Brno, Lawyer at the Organization for Aid to Refugees.

1 According to the Eurostat data, synthetized online at the web of European Commission, at $<$ ec.europa.eu/eurostat/statistics-explained/index.php/Migration_and_migrant_population_statistics\# Migration_flows> (accessed 20 August 2017); according to the United Nations, Department of Economic and Social Affairs Population Division in, European migration figures have increased from an estimated 49 million in 1990 to 58 million in 2000 to 70 million in 2010. Trends in International Migrant Stock: The 2008 Revision. United Nations database, POP/DB/MIG/Stock/Rev.2008), at <esa.un.org/migration/index.asp?panel=1> (accessed 20 August 2017).

2 UNHCR Beyond detention, Global strategy to support governments to end detention of asylum seekers and refugees, 2014-2019, 5, at <unhcr.org/53aa929f6.pdf> (accessed 20 August 2017); Arbogast, L et al, Migrant detention in the European Union: A thriving business. Outsourcing and privatization of migrant detention. Migreurop, July 2016, at <migreurop.org/IMG/pdf/migrant-detention-eu-en.pdf> (accessed 20 August 2017); Sampson, R and Mitchell, G "Global trends in immigration detention and alternatives to detention: practical, political and symbolic rationales" 1(3) Journal of Migration and Human Security (2013) 97. 
with the human rights of an individual, and therefore must be applied only as a measure of last resort, never as a general and, almost, automatic measure.

States are seemingly unable to comply with these strict rules imposed by international standards, with reference to the competing interest of securing migration control and public security in general. The formal purpose of immigration detention is a practical one, i.e. ensuring a certain law-previewed objective, such as realization of a transfer or expulsion. ${ }^{3}$ According to some authors, ${ }^{4}$ however, other motives, namely certain political objectives and the symbolic nature of detention of foreigners, can be just as strong a rationale as the practical one. A discussion on the practical rationales for detention points out that this may well be the reason for the continuous widespread use of detention. This is despite the lack of practical necessity and established legal barriers. Some authors argue that in fact, immigrant detention is predominantly, notwithstanding its legally divergent purpose, used as a punishment. ${ }^{5}$

Naturally, the article does not aim to study and describe comprehensively the relevance of those various motivations. Rather, the author seeks to synthesize both the latest European and international legal standards relating to the use of detention of migrants, with emphasis on standards relating to vulnerable groups such as children, with the rationale that states have for continuous widespread use of detention. The author argues that from the practical perspective, insistence on detention of high numbers of migrants is not rational. This is demonstrated through the description of potential alternatives and their ability to fulfil the declared objectives.

The author will first shortly review the relevant legal standards relating to detention of migrants in the EU together with recent jurisprudence and relevant soft-law documents and recommendations. Then, a short description of the practice of detention in EU member states will be offered; both with emphasis on the theory and practice of the use of alternatives to detention. Subsequently, the author will offer an elaboration on possible motivations of the use of detention and discussion of the effectiveness of detention in comparison to the alternatives to detention, according to the available data and research. The article will conclude arguing that in light of known alternatives to detention in migration control and their effects, for practical purposes, detention is rarely necessary. Therefore, political and symbolic rationales are rather a dominant reason in its continuous widespread use.

\section{Note on Terminology}

The terminology in this article is used in coherence with the Odysseus network study on alternatives to immigration and asylum detention in the EU published in 2015, for its comprehensiveness and relevance to the EU legal framework and practice. ${ }^{6}$ Immigrant detention is understood as the confinement of a migrant (including asylum-seekers) in a particular place with deprivation of their freedom of movement (Art. 2(h) of the recast

3 Leerkes, A, Broeders, D "A Case of Mixed Motives? Formal and Informal Functions of Administrative Immigration Detention" 50(5) British Journal of Criminology (2010) 830.

4 Sampson and Mitchell, supra nt 2.

5 Hernández, CCG, "Immigration Detention as Punishment" 61 UCLA Law review (2014) 1346.

6 Bruycker, P (ed), Bloomfield, A, Tsourdi, E, Pétin, J, Alternatives and immigration and asylum detention in the EU (Oddysseus Network 2015) at <odysseus-network.eu/wp-content/uploads/2015/02/FINALREPORT-Alternatives-to-detention-in-the-EU.pdf $>$ (accessed 20 August 2017). 
Return Directive $\left.{ }^{7}\right)$. Immigrant detention in this sense is a non-punitive administrative measure with the aim to fulfil a particular purpose (e.g. realization of transfer according to the Dublin regulation ${ }^{8}$ ). As such, the use of detention is under strict legal rules; one of which is the preference of alternatives to detention, i.e. detention can only be used if the alternatives cannot fulfil the purpose aimed for.

Alternatives to detention are therefore understood in this rather narrow sense, ${ }^{9}$ as measures that can only be applied if the legal conditions for the use of detention are met, but which do not comprise the deprivation of liberty. In certain cases, however, alternatives to detention can constitute restriction on freedom of movement. ${ }^{10}$

\section{The Law in the European Union}

This section will briefly examine the most relevant legislation and jurisprudence relating to the detention of migrants and asylum seekers in the EU; keeping in mind that according to the European Union Charter on Fundamental Rights (Art. 18), the EU asylum policy must respect the 1951 Refugee Convention, and that all EU Member States are also Member States to the Council of Europe Convention for the Protection of Human Rights and Fundamental Freedoms (herein ECHR). The legal standards will, therefore, be drawn also from the relevant UN and UNHCR documents, as well as the jurisprudence of the European Court of Human Rights (herein ECtHR).

In EU law, the detention of migrants and alternatives to it are defined in Directive 2013/33/EU of the European Parliament and Council of 26 June 2013, laying down standards for the reception of applicants for international protection (herein the recast Reception Directive); and Directive 2008/115/EC of the European Parliament and of the Council of 16th December 2008 on common standards and procedures in Member States for returning illegally staying third-country nationals (herein the recast Return Directive).

According to Art. 8 of the recast Reception Directive, a person can only be detained when it proves necessary in the individual case, if other less coercive alternative measures cannot be applied effectively, and with the aim of achieving one of the purposes listed in para. 3 of the Article, which must be precisely defined in national law. According to para. 4 of the same Article, alternatives to detention must also be laid down in national law. The Article explicitly mentions regular reporting to the authorities, the deposit of a financial guarantee, or an obligation to stay at an assigned place, as possible alternatives to detention. According to Art. 11, health (including mental health) must be of primary concern to the national authorities also for the purpose of an individual assessment of the necessity of detention, whilst minors must be detained as a measure of

7 Directive 2008/115/EC of the European Parliament and of the Council of 16 December 2008 on common standards and procedures in Member States for returning illegally staying third-country nationals.

8 Regulation No. 604/2013 of the European Parliament and of the Council of 26 June 2013 establishing the criteria and mechanisms for determining the Member State responsible for examining an application for international protection lodged in one of the Member States by a third-country national or a stateless person.

9 See Costello, C and Kaytas, E, Building Empirical Research into Alternatives to Detention: Perception of Asylum seekers and Refugees in Toronto and Geneva (UNHCR 2013), 10-11, at $<$ unhcr.org/protection/globalconsult/51c1c5cf9/31-building-empirical-research-alternatives-detentionperceptions-asylum.html> (accessed 20 August 2017).

10 See also the European Commission Asylum and Migration Glossary 3.0 (2014), at <ec.europa.eu/home-affairs/sites/homeaffairs/files/what-we-do/networks/european_migration_ network/docs/emn-glossary-en-version.pdf> (accessed 20 August 2017). 
last resort and after it has been established that other less coercive alternative measures cannot be applied effectively. The best interests of the minor must be a primary consideration in the decision-making process. Unaccompanied minors shall be detained only in exceptional circumstances.

The recast Return Directive puts standards in place that are similar to those in the recast Reception Directive. Detention for the purposes of removal of the migrant is only possible if other less coercive measures could not be applied effectively in the specific case, with the aim of achieving one of the listed purposes. The recast Return Directive particularly stresses the tight relationship between the detention and its purpose. According to Art. 4 of the recast Reception Directive, when it appears that a reasonable prospect of removal no longer exists, detention ceases to be justified and the person concerned shall be released immediately. Looking to Art. 17, unaccompanied minors and families with minors shall only be detained as a measure of last resort and the best interests of the child shall be a primary consideration in the decision-making process.

The effectiveness of such a measure, i.e. its ability to effectively lead to its declared purpose, is a precondition to its imposition; this is according to the jurisprudence of the Court of Justice of the European Union (herein CJEU) (e.g. the case of Sélina Affum, decision from 7th June 2016, C-47/15, or preceding case of Kadzoev, decision from 30th November 2009, C-357/09). Under the directives, therefore, one should take into account the requirements of legality (must be laid down with specific aims in the national law), necessity and proportionality (only when necessary and when other less coercive measures cannot effectively be imposed), together with the requirement of effectiveness of such a measure (can only be imposed if the proclaimed aim of detention can be effectively exercised).

Under ECHR standards, such detention must, under Art. 5, para 1 (f), also follow specific requirements, among which is the requirement of prescribed grounds for detention (requirement of legality), in the case of detention of migrants, to 'prevent effecting an unauthorised entry into the country or of a person against whom action is being taken with a view to deportation or extradition'. ${ }^{11}$ The close relation to the prescribed ground is necessary, otherwise the imposed measure is viewed as arbitrary, and will therefore not be in compliance with Art. 5 of the ECHR. ${ }^{12}$ The measure can also not be imposed in bad faith ${ }^{13}$ and is only in compliance with Art. 5 if there is a real existing possibility of fulfilling the proclaimed aim of detention ${ }^{14}$ and the state is actively taking steps to realize this aim in the shortest possible period of time. ${ }^{15}$ The ECtHR also requires states to use alternatives to detention or to justify, why alternatives were not effective in the particular case. ${ }^{16}$

11 Council of Europe, European Convention for the Protection of Human Rights and Fundamental Freedoms, as amended by Protocols Nos. 11 and 14, 4th November 1950, ETS 5, Art. 5 (f).

12 European Court of Human Rights, Amuur v. France, App no. 19776/92, 25 June 1996, para 50; Witold Litwa v. Poland, App no. 26629/95, 4 April 2000, para 78; Al-Jedda v. The United Kindgom [GC], App no. 27021/08, 7 July 2011, para 99.

13 European Court of Human Rights, A. and others v. The United Kindgom, App no. 3455/05 [GC] 19 February 2009, para 164.

14 European Court of Human Rights, Riad and Idiab v. Belgium, App no. 29787/03 and 29810/03, 24 January 2008.

15 European Court of Human Rights, M. and others v. Bulgaria, App no. 41416/08, 26 July 2011, para 75 a 76; Popov v. France, App no. 39472/07 and 39474/07, 19 January 2012; Chahal v. the United Kingdom [GC], App no. 22414/93, 15 November 1996, para 113.

16 European Court of Human Rights, Mikolenko v. Estonia, App no. 10664/05, 8 October 2009, Yoh-Ekale Mwanje v. Belgium, App no. 10486/10, 20 December 2011. 
Specific conditions, however, apply to vulnerable persons ${ }^{17}$ and particularly to children. Regarding detention of families with children or unaccompanied minors, the ECtHR grew increasingly strict in its latest jurisprudence. From considering the detention of children as unlawful particularly due to the conditions in the facilities and the length of detention; ${ }^{18}$ the recent jurisprudence stresses the emotional vulnerability of children, concluding that even a few days in a materially well-equipped facility can constitute ill treatment of a child. ${ }^{19}$ Detention of families with children or unaccompanied minors is therefore, in most circumstances, unacceptable under the ECHR.

Similar conditions apply under the universal human rights mechanisms of the United Nations, namely the International Covenant on Civil and Political Rights (herein ICCPR, regulating the deprivation of liberty in general) and the 1951 Refugee Convention (regulating the detention of asylum-seekers). According to the Art. 9 para 1 of the ICCPR, detention must be lawful, ${ }^{20}$ which also entails the requirement of prevention of arbitrariness, necessity, proportionality and preference alternatives. ${ }^{21}$ As such, immigration detention could be considered arbitrary if it is not necessary in all the circumstances of the case and proportionate to the ends sought, for example, to prevent absconding. ${ }^{22}$ Detention must be an exception rather than a rule; it must be imposed as a measure of last resort, where less coercive measures are not applicable. ${ }^{23}$ The use of alternatives is emphasized by, inter alia, General Comment No. 35 of the UN Human Rights Committee, ${ }^{24}$ which also states that detention should never be mandatory and must be left for individual assessment of necessity.

Detention of asylum seekers is regulated by the 1951 Refugee Convention, which states in Art. 31, para. 1, that states must not penalize refugees (and asylum seekers) for their irregular entry or stay in the country, if they subsequently (without delay) present themselves to the authorities and explain their case for irregular entry. However, restrictions to the freedom of movement can be imposed according to the Art. 31 para. 3, provided that these measures are necessary and applied only until their status is regularized; such a measure can also be administrative detention. Therefore, status of such asylum seekers is elaborated on by the United Nations High Commissioner for

17 European Court of Human Rights, E.g. a victim of trade in humans. See Rantsev v. Cyprus and Russia, App no. 5965/04, 7 January 2010.

18 European Court of Human Rights, Mubilanzila Mayeke and Kaniki Mitunga v. Belgium, App no. 13178/03, 12 October 2006; Muskhadzhiyeva and others v. Belgium, App no. 41442/07, 19 January 2010; Tarakhel v. Switzerland, App no. 29217/12, 4 November 2014; Popov v. France, Apps no. 39472/07 a 39474/07, 19 January 2012.

19 European Court of Human Rights, A. B. and others v. France, App no. 11593/12, A. M. and others v. France, App no. 24587/12; R. M. and others v. France, App no. 33201/11, R. K. and others v. France, App no. 68264/14, R. C. a V. C. and others v. France, App no. 76491/14, from 12 July $2 \mathrm{O} 16$.

20 UN Human Rights Committee General comment no. 35 on art. 9 - Liberty and security of a person, 2014, UN doc. CCPR/C/GC/35.

21 Nowak, M, U.N. Covenant on Civil and Political Rights - CCPR Commentary (2nd ed, N.P. Engel Verlag 2005); specifically Hugo van Alphen versus The Netherlands, Human Rights Committee communication no. 305/1998 para 5.8 .

22 Human Rights Committee, Danyal Shafiq v. Australia, Human Rights Committee communication no. 1324/2004, 2006; F.K.A.G. et Al. v. Australia, Human Rights Committee communication no. 2094/2011, 2013; Kwok v. Australia, Human Rights Committee communication no. 1442/2005, 2009; M.M.M. et Al. v. Australia, Human Rights Committee communication no. 2136/2012, 2013.

23 UN Human Rights Committee, supra nt 20.

24 Ibid. 
Refugees Guidelines on Detention (UNHCR, 2012) ${ }^{25}$ and further expanded by the UNHCR Global Strategy 'Beyond Detention'. ${ }^{26}$ Both documents emphasize that liberty and security of person are fundamental human rights and despite the legitimate aims states often pursue by detaining migrants, various studies show that alternatives to detention exist and are comparably effective. The action plan 'Beyond Detention' emphasizes that:

(p)utting people in detention has become a routine - rather than exceptional response to the irregular entry or stay of asylum-seekers and migrants in a number of countries. Some governments view detention as a means to dissuade irregular migration to or applying for asylum in their territories. While acknowledging that irregular entry or stay may present many challenges to States, detention is not the answer. $^{27}$

A particularly strong stance against detention of children was adopted in the Human Rights Committee General Comment No. 35 on Liberty and security of a person:

(c)hildren should not be deprived of liberty, except as a measure of last resort and for the shortest appropriate period of time, taking into account their best interests as a primary consideration with regard to the duration and conditions of detention, and also taking into account the extreme vulnerability and need for care of unaccompanied minors. ${ }^{28}$

According to the UN Committee on the Rights of the Child, children should not be subject to restrictive measures due to the immigrant status of their parents. Furthermore, if they are detained due to their irregular status, this constitutes a breach of the child's rights and is always contrary to their best interests. ${ }^{29}$ The Special Rapporteur Against Torture repeated this opinion in the report from 2015, stating that detention of migrant children is always contrary to their best interests and that children who are in administrative detention with their parents should be released immediately. ${ }^{30}$

\section{The Practice in the European Union}

Despite clear and strict standards, data shows that the number of persons detained within the European Union due to migration reasons is increasing in the long run. According to the Migreurop data, the number of individuals in immigration detention in the United Kingdom rose from 250 people in 1993, to 2,260 in 2003 and 28,909 in 2012, while in France it increased from 28,220 in 2003 to 51,385 in $2013 .{ }^{31}$ In the Czech Republic,

25 UNHCR Detention guidelines, 2012, at <unhcr.org/publications/legal/505b10ee9/unhcr-detentionguidelines.html> (accessed 20 August 2017).

26 UNHCR Beyond Detention, Global strategy to support governments to end detention of asylum seekers and refugees, 2014-2019, 5, at <unhcr.org/53aa929f6.pdf> (accessed 20 August 2017).

27 Ibid.

28 UN Human Rights Committee, supra nt 20.

29 Concluding observations of the UN Committee on the Rights of the Child towards the Czech Republic, 2003, UN doc. CRC/C/15/Add.20, para 57.

30 Mendez, J, The report of the UN Special Rapporteur Against Torture. 5. March 2015, UN doc. A/HRC/28/68, para 51-52.

31 The figure, however, reflects only detention facilities capacity. Migreurop, 2014, at $<$ http://en.closethecamps.org/2014/03/03/europe-of-camps-deploys-its-web/> (accessed 20 August 2017). 
where data on detained migrants is available, the number of detainees increased from around 350 in 2013 to 4,822 in 2014; and 8,563 in 2015. ${ }^{32}$ According to the Parliamentary Assembly of the Council of Europe, the member states have 'significantly expanded their use of detention as a response to the arrival of asylum seekers and irregular migrants' ${ }^{33}$

Potential alternatives to detention are only available in 24 member states and include reporting obligations, residence requirements, the obligation to surrender their identity or travel documents, release on bail, electronic monitoring, the provision of a guarantor, or being released to cooperate with care workers or under a care plan. Community management programmes are not available in any of the member states. In 2013, the countries, which provided the largest number of third-country nationals with an alternative to detention were France $(1,258)$, Austria (771), Belgium (590) and Sweden (405). Sometimes, alternatives are available under the law, but never used in practice. ${ }^{34}$

The most frequently used alternatives are reporting obligations (used in 23 states), residence requirements (18 states), the obligation to surrender a travel document (15 states) and releasing the individual on bail (13 states). Electronic monitoring (e.g. tagging) and guarantor requirements are used in four states, while individual states also arrange the release of the individual to a care worker under a care plan, organize voluntary return programs, accommodation in open centers and guardianship as different options. The detention of vulnerable persons (such as children) is either explicitly prohibited or possible only in exceptional circumstances. ${ }^{35}$ However, under this study, the 'placement' of a child together with their parents in detention facilities is not considered to be detention, which is contrary to the ECtHR approach. ${ }^{36}$

Overall, the practice varies significantly throughout the EU member states. According to the Odysseus Network research (2015), practical considerations significantly influence the decision whether to utilize an alternative to detention or not. For example, due to the administrative convenience, detention is much more common in Dublin transfers. Detention also often occurs if the person does not have a stable residence. ${ }^{37}$ Very few external actors, such as non-governmental organizations, were, according to the Odysseus Network research, ${ }^{38}$ involved in implementing alternative schemes. Community-based accommodation and services as an alternative were not implemented in any of the EU countries. Community-based accommodation and

32 European Migration Network (EMN) Czech National Contact Point (NCP) (the Department for Asylum and Migration Policies of the Ministry of the Interior), The use of detention and alternatives to detention in the context of immigration policies, 2014, at <ec.europa.eu/dgs/home-affairs/what-wedo/networks/european_migration_network/reports/studies/results/index_en.htm> [hereafter, the EMN 2014] (accessed 20 August 2017); Noviny, C, Czech police detain 8175 illegal foreigners this year. 18 December 2015, at <ceskenoviny.cz/zpravy/czech-police-detain-8175-illegal-foreigners-thisyear/1294611> (accessed 20 August 2017).

33 Parliamentary Assembly, Council of Europe, Doc. 12105, 11 January 2010, at <assembly.coe.int/nw/xml/XRef/Xref-DocDetails-EN.asp?FileID=12435\&Lang=EN> (accessed 20 August 2017).

34 Such is the case of the Czech republic, where release on bail as an alternative to detention has not been used in practice. EMN, 2014, supra nt 32, 35.

35 Ibid, 4.

36 European Court of Human Rights, Popov v. France, Apps no. 39472/07 a 39474/07, 19 January 2012.

37 Bruycker, supra nt 6.

38 Ibid. 
services involve the integration and subsequent supervision of an individual within the local community which, arguably, can be an effective migration control tool. ${ }^{39}$

In general, it is obvious that while the European Union framework did motivate some states to adopt alternatives to detention, these standards have not always impacted upon the use of detention; in some states (such as Germany), detention dropped significantly due to the use of alternatives, while in others (such as the UK or the Czech Republic), there is a steady increase in the number of migrants being detained. In some states, alternatives are not even foreseen by law (Malta), whilst in others they are not applied in practice (Greece). In others, the use of alternatives is rather rare and usually only applied in asylum cases. ${ }^{40}$

\section{Motivations for Detention}

According to Sampson and Mitchell, ${ }^{41}$ the motivations to detain migrants are, in principle, threefold: practical, political and symbolic. Practical motivation relates to the formal purpose of detention prescribed by law, i.e. the prevention of absconding and ensuring compliance with the procedure. ${ }^{42}$ Political motivations, meanwhile, take into account the current political climate rather than rational arguments, and respond to different political pressures. ${ }^{43}$ Symbolic motivations ${ }^{44}$ are those aiming to send a message of control and sovereign authority over the territory; the message can be of ensuring stability and security to the general public, or of deterrence to the migrant population. Political and symbolic motivations are not prescribed by law, and therefore cannot be the formal grounds for detention, yet they remain a strong factor influencing the ratio of the use of detention and its alternatives. ${ }^{45}$ This section will briefly examine those three types of motivation and the potential of alternatives to detention to address them.

\section{A. Practical/Formal Motivations}

Regarding the practical and formal motivations, the use of alternatives to detention rises when they are proven to achieve the declared goal of the detention, i.e. when they meet the declared objectives. If high rates of compliance (not absconding, compliance with the process) are shown, the use of alternatives is rational. ${ }^{46}$ At the same time, the high compliance rate can be achieved by many alternative options. ${ }^{47}$

39 Sampson and Mitchell, supra nt 2; Field, O and Edwards, A, Alternatives to Detention of Asylum-Seekers and Refugees (UNHCR, 2006), paras 126-128, at <unhcr.org/protection/globalconsult/4474140a2/11alternatives-detention-asylum-seekers-refugees-ophelia-field.html > (accessed 20 August 2017).

40 Bruycker, supra nt 6

41 Sampson and Mitchell, supra nt 2.

42 Leerkes and Broeders, supra nt 3.

43 These can be, inter alia, the media and public's negative reaction to increased migration or, on the other hand, a pressure from international bodies to comply with human rights obligations.

44 Ibid; also Welch, M, Schuster, L "Detention of Asylum Seekers in the UK and USA: Deciphering Noisy and Quiet Constructions" 7(4) Punishment \& Society (2005) 397.

45 As documented for example in Ibid.

46 Sampson, R, Robyn C, Mitchell G and Bowring, L, There Are Alternatives: A Handbook for Preventing Unnecessary Immigration Detention (International Detention Coalition 2011).

47 Ibid; Costello and Kaytas, supra nt 9; Edwards, A, Back to Basics: The Right to Liberty and Security of Person and 'Alternatives to Detention' of Asylum-Seekers, Stateless Persons, and Other Migrants (UNHCR, 2011), UN doc. PPLA/2011/01.Rev.1 (hereinafter: Edwards 2011a); Edwards, A, "Measures of First Resort: Alternatives to Immigration Detention in Comparative Perspective" 7 The Equal Rights Review (2011), 117 (hereinafter Edwards 2011b). 
Research shows that the difference between the compliance rate for persons in detention and persons under alternative measures is rather low. ${ }^{48}$ Edwards,${ }^{49}$ for example, shows the compliance rate to be between $80 \%$ and $99 \%$ in different countries, both for groups of asylum seekers and persons awaiting deportation under alternatives to detention. Compared with criminal law detention, where compliance of offenders released under non-custodial measures usually ranges from $40 \%$ to $70 \%$, it is a rather effective tool. ${ }^{50}$ It has also been identified that there are factors which influence the effectiveness of an alternative measure, such as:

(a) providing legal advice; (b) ensuring that asylum seekers are not only informed of their rights and obligations but also that they understand them, including all conditions of their release and the consequences of failing to appear for a hearing; (c) providing adequate material support and accommodation throughout the asylum procedure; (d) screening for either family or community ties or, alternatively, using community groups to "create" guarantors/sponsors. ${ }^{51}$

Obviously, one of the most important factors is whether, and how, the alternatives are available in practice, and not only in law. ${ }^{52}$

Using the model from the European Migration Network report, a reasonable balance must be struck between four factors: firstly, reaching a prompt and fair decision in the procedure; secondly, by reducing the risk of absconding; thirdly, by maximizing cost-effectiveness and finally by ensuring respect for fundamental rights. ${ }^{53}$ Regarding the first factor, no significant difference was found in the length and effectiveness of the procedure to determine whether the person was to be put in detention or under an alternative measure, whilst the costs of detention were significantly higher than those of the alternatives. ${ }^{54}$ While the additional costs in terms of energy and money may be an obstacle, the long-term cost-effectiveness of the alternatives is generally much better. ${ }^{55}$ According to the Odysseus network research, detention is inherently more expensive than the alternatives. In Canada, detention was 93\% more expensive, while in Australia, detention costs exceeded those of the alternatives by $69 \%$. Generally, using alternatives to detention will save approximately $70 \%$ of the overall costs. ${ }^{56}$ The research also found that individual rights are more often compromised while in detention than they are under the alternatives, and that the risk of absconding is slightly, but not considerably, higher under the alternatives. ${ }^{57}$ Overall, the cost-benefit analysis of available data shows that using alternatives to detention is rather a rational choice from the practical motivations perspective.

48 EMN 2014, supra nt 32, 37.

49 Edwards 2011a, supra nt 47, 82.

50 Field and Edwards, supra nt 39, 24.

51 Ibid, 45 .

52 Ibid, 47.

53 EMN, supra nt 32, 37.

54 Ibid.

55 Field and Edwards, supra nt 39, paras 166-172.

56 Bruycker, supra nt 6, 23.

57 Ibid, 41. 


\section{B. Political Motivations}

Political motivations are, according to Sampson and Mitchell, another major factor influencing the decision to use alternatives to detention. It is argued that a number of alternatives are introduced largely due to international and national criticism of the policy of detention, either from the perspective of its impact on migrants' lives and wellbeing ${ }^{58}$ or from the perspective of international law. At the same time, however, the detention of migrants has become a highly politicized issue due to the influence of the national press. Additionally, alternatives are not introduced or used in practice because the decision-makers understand that a hard stance against migrants will bring them a political advantage. ${ }^{59}$ Sampson and Mitchell point out the risk of prioritizing some groups of migrants (e.g. children) due to political reasons at the expense of other, not frequently emphasized groups. ${ }^{60}$

\section{Symbolic Motivations}

From the media and other sources, such as public statements of politicians, as well as the reasoning regarding the practical implications of the use of alternatives to detention, it remains that the dominant motivation for the continuing decision to detain migrants is probably for its symbolic nature of demonstrating control over the territory of the state, i.e. demonstrating the State's devotion to protecting the security of its nationals. ${ }^{61}$ For example, it was explicitly stated on the website of the Czech Ministry of Interior that the main purpose of the automatic detention of migrants arriving within the Czech territory in 2016 was to 'send a message' to those arriving in the Czech Republic that they should 'stay outside the Czech border'. The intentionally horrible treatment of migrants to deter their entrance to the Czech Republic was repeatedly criticized by various international bodies, ${ }^{62}$ yet remained in place probably as an attempt to address the afore-mentioned political pressures. It should be noted that there is no empirical evidence that the detention of migrants deters them from seeking asylum or entering the territory. Rather, the ratio between entering migrants and the use of detention remains constant, and globally, migration has been increasing despite the use of detention. ${ }^{63}$

Sampson and Mitchell ${ }^{64}$ suggest the use of The Community Assessment and Placement Model, which can address all of the previously mentioned motivations, including the symbolic one. They claim that this model can constitute an effective migration management tool and, thus, fulfil the 'symbolic' needs of the decision-makers all the more effectively when coupled with the cost-effectiveness rationale. At the same time, the 'migration management' rather than the 'border control' rhetoric can be

58 Sampson and Mitchell, supra nt 2, p. 106; also Coffey, GJ, et al, "The Meaning and Mental Health Consequences of Long-Term Immigration Detention for People Seeking Asylum" 70(12) Social Science \& Medicine (2010) 2070, which references related research on the topic.

59 See, for example, the story in New York Times on the dynamics between the public, the media and the politics in managing migration. Spinning the migrants: How a media mogul helped turn Czechs against refugees, New York Times. 13 September 2016, at <economist.com/news/europe/21707125-politicscentral-and-eastern-europe-are-increasingly-driven-businesses-own-media> (accessed 20 August 2017).

60 Sampson and Mitchell, supra nt 2, 106.

61 Leerkes and Broeders, supra nt 3; Welch and Schuster, supra nt 44.

$62 \mathrm{Hu} \square$ seynov, L, Detention of irregular migrants: CPT standards, 2011, at <fra.europa.eu/fraWebsite/frc2011/ docs/Latif-Huseynov-FRA-Conference-2011.pdf> (accessed 20 August 2017).

63 Edwards 2011a, supra nt 47, 2.

64 Sampson and Mitchell, supra nt 2, 108-109. 
coupled with other strategies to oversee migrants in the community with comparable effects and yet be a more visible symbol of successful management. ${ }^{65}$

\section{Conclusion}

This article argues that while there is a growing use of immigration detention in the European Union member states, the legal barriers coupled with a pragmatic rationale should lead to its reduction and preferably to the use of alternatives. The article builds on how the rhetoric for detention can be divided into three types of rationales: the pragmatic, political and symbolic, with only the pragmatic being capable of providing a formal ground for detention under international and European law. However, available data shows that introducing alternatives to detention is, in fact, more pragmatic with regards to the relationship between decisive factors such as: the length and effectiveness of procedures, the risk of the migrant absconding, cost-effectiveness and the human rights impact.

Despite the fact that detaining migrants for reasons other than formal or practical purposes is not permissible under law, it remains that more often than not it has in fact been used to send a political or symbolic message, for example as a deterrent to other potential migrants. This article, thus, argues that other models, such as focusing on the 'management of migration' in the community rather than 'border control', can be introduced to pursue the same objective.

www.grojil.org

${ }^{65}$ Ibid, 107-109. 